\title{
Influence of nursing pathway implementation to length of stay on neurologic patients
}

\begin{abstract}
Lenght of stay is indicator of serving quality and nursing care to measure hospital efficiency level. Neurology ward is one of the wards that experience increasing of length of stay from 5,91 to 7,38 . The cause of length of stay increasing is nursing care management that according to Calhoun can be formulated to nursing clinical pathway. The purpose of this study is to analyze influence of nursing clinical pathway implementation to length of stay of non hemorrhagic stroke patients in neurology ward Bukitttinggi Achmad Mochtar Hospital. The designs of this study used non-equivalent post test only control group design approach. Sample of this study were taken by purposive sampling with total of 32 samples consist of 16 sample as intervention group and another 16 samples as control group. Data analyzing used t-test independent. The result shows that there is significant influence for average length of stay of stroke non hemorrhagic patients that were given nursing clinical pathway compared to the group that is not given nursing clinical pathway with $p$ value 0,001 ( $p$ value $\leq 0,05$. According to this study, hospital should implement nursing clinical pathway when doing nursing care to patients in ward and also hospital should make policy related to nursing clinical payhway implementation.
\end{abstract}

Keywords: quality, length of stay, nursing clinical pathway
Volume 5 Issue 6 - 2018

\author{
Rezkiki F,' Dharma S, ${ }^{2}$ Yasmi ${ }^{3}$ \\ 'STIKes Fort De Kock, Indonesia \\ ${ }^{2}$ Faculty of Pharmacy, Andalas University, Indonesia \\ ${ }^{3}$ Faculty of Nursing, Andalas University, Indonesia
}

Correspondence: Rezkiki Fitrianola, STIKes Fort De Kock, Fort De Kcok Health Science Institute, Indonesia, Tel +6285264341991, Email fitreanola.rezkiki@gmail.com

Received: July 19, 2017 | Published: November 16, 2018

\section{Background}

Indicators of assessment of service quality and nursing care to measure the level of efficiency of the hospital one of them is determined by the length of the day of care or known as LOS (length of stay). The length of hospital day is used to measure the efficiency of hospital services that cannot be done alone but must be shared with the interpretation of Bed Turn Over (BTO) and Turn Over Interval (TOI). In general, the value of the ideal day of stay based on the minimum service standard of Depkes RI is $\leq 6$ days. ${ }^{1,2}$ The length of the day of treatment is influenced by several factors, one of which is the health worker who handles the patient. The health worker who handles the patient has enough role in determining the length of the length of stay, where the difference in skill between doctor and nurse will affect the performance in case handling. Nurses are health workers who have a long time to interact with patients (Wartawan, 2011).

According to (Byron, 2000) states that management of nursing care in which there is a nursing process can be developed in the patient care pathway or better known as clinical pathway. The nursing process provides a framework in establishing a clinical pathway. A brief review of the nursing process with a discussion of how to incorporate every element of the framework will lead to the achievement of the goal. Implementation of clinical pathway can be one alternative management of nursing care to improve nursing care.

Clinical pathway has many advantages, besides it should be noted also the shortcomings encountered in its application, among others, the apparent nursing process is obvious because it must adjust to the stages of medical planning, treatment, and other investigations. Reality in the field, nursing profession is still not maximal in the preparation of clinical pathway, especially in terms of documentation, given the nursing documentation so far contains about the activity of nursing very much and not using the standard language. Conditions that make the concept of clinical pathway that developed in Indonesia, its contents dominated by a certain profession, while the nurses who were near the patient for 24 hours almost no action was taken. In terms of overcoming the problem it would be nice nursing profession begins by making a formulation for clinical pathway that can be called the nursing clinical pathway where the process of nursing care can enter into multidisciplinary other professions to manage patients. ${ }^{3}$

Dr. Hospital Achmad Mochtar (RSAM) Bukittinggi is one of the hospitals that gradually seeks to improve itself in order to provide quality health services. The average length of patient day (LOS) in RSAM Bukittinggi as of September 2013 was 5.42 which increased compared to LOS as of August 2013 of 4.76. One of the RSAM rooms that experienced a significant increase in LOS per September 2013 is the room of Neurology which initially increased to $5.917 .38 .^{4}$

Neurology Room RSAM Bukittinggi manages various patients with complaints of neurological disorders, including patients with stroke. Stroke is a clinical syndrome with symptoms of focal or global brain dysfunction, which can cause death or persistent abnormalities for more than 24 hours, without any cause other than vascular disorders. Stroke is generally known two kinds of non hemorrhagic stroke (ischemic stroke) and hemorrhagic stroke. About 80 to $85 \%$ of strokes are ischemic stroke (Ruamantir, 2007). ${ }^{5}$

In 2000, of all stroke patients admitted to the hospital ward of neurology RSUP H. Adam Malik Medan, $65.49 \%$ of them were ischemic stroke patients. The risk of death within the first 30 days after an ischemic stroke is $8 \%$ to $20 \%$. While in Bukittinggi RSAM non-hemorrhagic stroke included the top ten causes of death of inpatients. ${ }^{6,7}$

According to baseline data obtained from one of the treatment rooms at Siloam Hospital Lipo Village (SHLV), which is a special 
treatment room for stroke patients, it was found that in August 2011 the number of non hemorrhagic stroke patients was 28 people with an average length of day of treatment 7 days. Roza research, ${ }^{8}$ obtained the average length of day of non sterile hemorrhagic patients in RSCM is 8.1 days. The audit report of non hemorrhagic stroke management of inpatients in RSDM Surakarta was found that the days of treatment of non hemorrhagic stroke patients were 11 days.

Preliminary study results found that there is no application of nursing clinical pathway especially for patients with non hemorrhagic stroke in Room Neurology RS RS. Achmad Mochtar Bukittinggi. The results of interviews with the head of the RSAM Neurology Room stated that the neurology room already has Standard Operating Procedures (SOP) and Nursing Care Standards (SAK) as guidance in performing nursing actions to the patient, but there is no nursing care form summarized in the form of nursing clinical pathway. The average length of days of non hemorrhagic stroke patients in the RSAM Neurology Room is 7 to 8 days.

Based on the background as well as the problems in the above description, the researchers feel interested and felt the need to do research on the effect of the application of nursing clinical pathway on the length of the day of treatment of non hemorhagic stroke patients in Dr. Achmad Mochtar Bukittinggi.

\section{Methodology}

This research uses quasi experiment design with non-equivalent approach of post test only control group design. This design aims to examine the causal relationships by providing intervention (treatment) to the experimental group, then the outcomes of the intervention are compared with the retrospective retracted control group. ${ }^{9}$ This study was designed to determine the length of days of non hemorrhagic stroke patients after being given nursing clinical pathway. The study was conducted in the neurological space of RSAM Bukittinggi. The population in this study was all non hemorrhagic stroke patients in RS Neurology Room. Dr. Achmad Mochtar Bukittinggi 2014 with the number of 52 people counted from January to March 2014. The sample in this study was selected by using the technique of non probability sampling with purposive sampling approach which is divided into two groups namely the intervention group and the control group consisting of 16 person.

Non-hemorrhagic nursing clinical pathway stroke (attached) is an indication for researchers to determine the steps in administering nursing clinical pathway interventions in non hemorrhagic stroke patients. These guidelines begin with patient characteristics including age, sex, history of Diabetes Mellitus, laboratory (Lipid and GDR); Laboratory examination covering stages of non-hemorrhagic nursing clinical pathway stroke implementation.

Data collection in the intervention group was conducted by giving the 16 respondents nursing clinical pathway that had been prepared by the researcher, starting from the first day of treatment until the patient was allowed to go home. Respondents in this study involved families. Non-hemorrhagic nursing clinical pathway stroke is given in accordance with the critical elements including neurology, psychosocial, nutrition/hydration, ventilation, circulation, elimination, pain, skin integrity, mobilization and education. Data collection in the control group was done by retrospective technique that is by seeing the nursing care according to hospital standard which seen through the status of developmental record of non hemorrhagic stroke patients who had been treated in RSAM Bukittinggi before.

\section{Results}

Length of stay care of non hemorrhagic stroke patients who are not given nursing clinical pathway (Table 1).The results showed that the average length of patient days that was not given nursing clinical pathway was 7 days (6.94 days). The same study conducted by Paul ${ }^{10}$ which shows the length of day care of non-hemorrhagic stroke patients treated at the hospital on average is 9.7 days. Ranette's ${ }^{11}$ study also showed that the average length of day of non-hemorrhagic stroke patients in RSCM was 8.1 days.

Table I Length of Stay Treatment of Non Hemorrhagic Stroke Patients in RSAM Neurology Room Control Group Year $2014(n=16)$

\begin{tabular}{lllll}
\hline Length of Stay & $\mathrm{n}$ & Mean & Std. Deviation & $\begin{array}{l}\text { Minimum- } \\
\text { Maximum }\end{array}$ \\
I & 2 & 3 & 4 & 5 \\
Control Group & 16 & 6.94 & 1.063 & $6-10$ \\
\hline
\end{tabular}

The above research shows that the average length of patient day that is not given by nursing clinical pathway is almost the same, which when compared to Depkes standard, ${ }^{12}$ the length of the day is extended from standard for 6 days. But when compared with the evidence-based duration of day of non stroke hemorrhagic patients (8-9 days), then the length of the day is still within normal limits.

In this study patients who were not given nursing clinical pathway received nursing care as is usually provided by nurses at the hospital. The data taken are retrospective data where the researcher see the documentation of nursing care that has been given by nurses in neurology room of RSAM Bukittinggi.

Research (Nurlina, 2013) explains that the implementation of nursing care is the responsibility of nurses in implementing nursing care in patients through the provision of quality nursing care by using the standards of nursing care as a guide nurses in implementing nursing care.

From the observation results obtained that neurological physical examination is not done nurses as a whole. The nurse only documented a general decline in neurological function that occurs in patients such as the right weak limb or left parity, but there is no documented physical examination involving 12 cranial nerves. No documented development of patient breathing sounds, pain and emotional support where the three elements greatly affect the nursing actions required by patients. Inspection of documented vital signs every nurse shift serve, but the range of checking distance at $6: 00 \mathrm{pm}$ to $6: 00$ hours is too long to monitor the progress of patient's blood pressure status as a determinant of non-hemorrhagic stroke events, where the data obtained in that hour span allows for an increase in blood pressure Which is significant. The recording of muscle strength is documented from the beginning of the assessment until the patient returns. At the interview with the head of the room, it was found that the room nurse rarely teaches passive and active ROM exercises in the patient, because the workload of the nurses in the high room is visible from the number of nurses who are not proportional to the number of patients in the room. ${ }^{13}$

Length of Stay care of non hemorrhagic stroke patients given nursing clinical pathway (Table 2). ${ }^{14}$ Based on the data analysis, the average length of patient days that is not given by nursing clinical pathway is 5,25 compared to Ministary of Health, ${ }^{1}$ the length of stay is within normal limits which is less than 6 days and when compared with Evidence based on the length of days of non hemorrhagic stroke 
patients (8-9 days), then the length of the day is more shortened.

Table 2 Length of Stay Treatment of Non Hemorrhagic Stroke Patients in RSAM Neurology Room At Treatment Group Year $2014(n=16)$

\begin{tabular}{ccccc} 
Length of Stay & $\mathrm{n}$ & Mean & Std. Deviation & Minimum-Maximum \\
I & 2 & 3 & 4 & 5 \\
Treatment Group & 16 & 5.25 & 1.038 & $4-8$ \\
\hline
\end{tabular}

In this study, researchers took the format of nursing clinical pathway non-hemorrhagic stroke from Bloomington Hospital, Canada which was previously validated first using content validity (content validity). ${ }^{15-18}$ The instrument of nursing clinical pathway helps nurses to be more focused on providing holistic nursing care, this is because nursing clinical pathway non hemorrhagic stroke contains about the fulfillment of nursing care which refers to nursing intervention clarification (NIC), namely; Fulfillment of neurological, psychosocial, nutrition and hydration needs, ventilation, circulation, elimination, pain, skin integrity, mobilization and education.

Nursing clinical pathway describes the steps of nursing care systematically began to enter the hospital until discharge from the hospital, in this study is nursing care in non hemorrhagic stroke patients. This is in accordance with those disclosed by (Byron, 2000), that nursing care standards that include assessment, diagnosis, nursing plans, nursing implementation and evaluation can be used as a framework within the nursing clinical pathway.

Continuous resolution of each patient requirement status summarized in nursing clincial non-hemorrhagic stroke pathway, the length of the patient's day care can be controlled, due to the regular actions performed by the nurse and focusing on the patient's complaints each day, and the collaborative actions undertaken each A change in the condition of the patient. Nursing clinical pathway facilitates the documentation and communication of nurses so as to speed up the nursing service in accordance with the needs of patients, it also directly accelerate the healing process of patients and accelerate the long days of hospitalization.

Effect of non-hemorrhagic nursing clinical pathway stroke application on patient duration (Table 3). Based on the results of data analysis, it can be said that the accepted hypothesis is that the group treated with nursing clinical pathway shortens the length of the day of treatment is 5.25 days compared to groups that are not treated by nursing clinical pathway that is for 6.94 days. The statistical results obtained $p$ value $=0.001$ which means there is a significant influence between the length of day care of non-hemorrhagic stroke patients treated nursing clinical pathway with no treatment given.

Table 3 The effect of non-hemorrhagic nursing clinical pathway stroke on the length of stay At RSAM Bukittinggi

Year $2014(\mathrm{~N}=32)$

\begin{tabular}{llllll}
\hline Length of Stay & $\mathrm{n}$ & Mean & $\begin{array}{l}\text { Std. } \\
\text { Deviation }\end{array}$ & Minimum-Maximum & $\mathrm{p}$ value \\
\hline (1) & $(2)$ & $(3)$ & $(4)$ & $(5)$ & $(6)$ \\
\hline Treatment Group & 16 & 5.25 & 1.038 & $4-8$ & 0.001 \\
\hline Control Group & 16 & 6.94 & 1.063 & $6-10$ & 0 \\
\hline
\end{tabular}

The length of day care is one of the indicators of nursing care quality to measure the efficiency level of the hospital. Based on the minimum service standard of hospital Ministary of Health RI, ${ }^{1}$ the duration of the ideal day is $\leq 6$ days and if compared with the old evidence based on day non stroke hemorrhagic treatment is 8 - 9 days. The results of this study found that the duration of non-hemorrhagic stroke patients treated by nursing clinical pathway was 5.25 days, which means that the length of the ideal patient day according to the Ministary of Health $\mathrm{RI}^{1}$ and shortened when compared with the old evidence based on day of stroke treatment Non hemorrhagic.

The length of day care is influenced by several factors, one of which is the health worker that is the nurse. The nurse who provides nursing care to the patient has enough role in determining the lengthening and shortening of the length of the day of care, because the nurse is a health worker who has long time intensity in interacting with the patient (Wartawan, 2012).

Respondents who received treatment in the form of nursing clinical pathway more get nursing care as a whole, making it easier for nurses to control every health development of patients summarized in documentation nursing clinical pathway. This opinion is corroborated by Louise, 2005, that clinical pathway is used to facilitate the documentation of the journey of a clinical action in this case is a selfdirected nursing action or a brief and communicative collaboration. Similarly, research, ${ }^{3}$ which states that clinical pathway is a health care planning document that includes a nursing service that summarizes every step taken to the patient starting hospital admission to hospital out of evidence-based nursing standards with results Can be measured.

The effect of non-hemorrhagic nursing clinical pathway stroke on the length of hospital day can be elaborated through each critical elements and developmental status in nursing clinical pathway format which refers to nursing intervention clarification (NIC).

\section{Summary}

From this study it can be concluded that the length of day of non stem hemorrhagic stroke patients is not ideal in groups that are not given nursing clinical pathway intervention, the duration of the day of treatment of non hemorrhagic stroke patients is ideal in the group given nursing clinical pathway intervention, there is a significant effect of long-term Day care of non hemorrhagic stroke patients provided with nursing clinical pathway with no intervention. This means that nursing service institutions are expected to use nursing clinical pathway to be applied in providing nursing care to inpatients, especially non hemorrhagic stroke patients. The goal is to accelerate the length of patient day care, and facilitate the nurses in documenting and communicating about the development of patient health comprehensively, it is necessary to apply written policy from hospital leaders and nursing field to be able to carry out nursing clinical pathway in the inpatient room by forming team in formulating nursing clinical Pathway in every inpatient room followed by socialization to every head of the room and nurses implementer. For the head of the room needs commitment in controlling nurses implementing in providing nursing care to patients. For implementing nurses, it is also necessary work commitment of nurse executing to carry out nursing clinical pathway in giving nursing care to inpatient. For further research, it is necessary to do continuous research using various research methods such as in-depth interview method for qualitative related to the form of patient satisfaction after nursing clinical pathway by nurse and nurse work commitment in implementing nursing clinical pathway.

\section{Acknowledgements}

Infinite gratitude to the Dean and Chairman of the Master 
Program of Nursing Management UNAND, Supervisor I and mentor 2, Chairman STIKes Fort De Kock and staff and all friends in arms especially nursing department who has helped a lot. Director of TSAM BUkittinggi who has given permission to undertake research, Head of the neurological space of RSAM Bukittinggi and staff who have facilitated researchers in conducting research, and all those who have assisted in the research and writing of this manuscript. Without the help and guidance of various parties, it is very difficult for researchers to complete this research. The researcher hopes Allah SWT is willing to repay all the good of all parties who have helped. Hopefully this research brings benefits for the development of nursing science in particular.

\section{Conflicts of interest}

Author declares that there is none of the conflicts.

\section{References}

1. Menteri Kesehatan Republik Indonesia. 2008:1-8.

2. Puspitarini R, Tri Lestari, Riyoko. Analisis average length of stay (AvLOS) pasien rawat inap pada kasus typhoid fever di rumah sakit umum daerah Sragen periode tri wulan IV tahun 2008. APIKES Mitra Husada Karanganyar. 2009;3(1).

3. Yasman Y. Penerapam integrated care pathways (ICP) sebagai bagian sistem informasi manajemen keperawatan di rumah sakit. 2012.

4. Rahma PA. Implementasi clinical pathway untuk kendali mutu dan kendali biaya pelayanan kesehatan. Majalah Dental. 2013.

5. Agustina. Prevalensi stroke iskemik pada pasien rawat inap di RSUP Fatmawati Jakarta Selatan pada tahun 2008. Jakarta: Universitas Islam Negeri Syarif Hidayatullah; 2009.

6. Price SA, Wilson LM. Patofisiologi. Konsep Klinis Proses-Proses Penyakit. 4 ed. In: Jakarta EGC editor. 2006.
7. Lyrawati D. Arteriogenesis dan Angiogenesis pada stroke hemoragik. mempertajam konsep untuk memperoleh manfaat terbaik neovaskularisasi. Jurnal Kedokteran Brawijaya. 2008;24(1):44-51.

8. Roza R. Lama hari rawat pasien stroke di RSCUPN CiptoMangunkucumo dan faktor-faktor yang mempengaruhi. 2010.

9. Arikunto. Prosedur penelitian, suatu pendekatan praktek cetakan ketigabelas Jakarta: Rineka Cipta. 2006.

10. Laporan audit penatalaksanaan stroke non hemoragic pasien rawat inap di rsdm surakarta. 2012.

11. Ranette T, Kinsman L, James EL, et al. Clinical Pathway: Effect on profesional practice, patient outcomes, length of stay and hospital costs. Germany: The Cochrane Collaboration; 2010.

12. Hastono. Basic data analysis for health research training: Analisis data kesehatan. Depok: FKMUI. 2007.

13. Marlina. Pengaruh latihan Range of Motion (ROM) terhadap peningkatan kekuatan otot pada pasien stroke iskemik di ruang rawat saraf Rumah Sakit Umum Daerah Dr. Zaenal Abidin Banda Aceh. Idea Nursing Journal. 2011;3(1):1-10.

14. Bloomington. Neuroscience services ischemic, hemorrhagic stroke clinical pathway. Indiana. 2009.

15. Calhoum. Uncomplicated pregnancy: Clinical pathway genesis based on the nursing process. ProQuest Nursing \& Allied Health Source. 2000.

16. Hospital, Bloomington. Ischemic hemorrhagic stroke clinical pathway. Bloomington, Indiana. 2009.

17. Nursalam. Manajemen keperawatan aplikasi dan praktek keperawatan profesional. Jakarta: Salemba Medika. 2011:1-564.

18. Departemen Kesehatan RI Pusat Pendidikan Tenaga Kesehatan. Perawatan 1: Dasar-dasar keperawatan. Jakarta: Depkes RI. 2005. 